\title{
Spatial Pattern of Bathymetry in Wangi-Wangi Island and its Surrounding Based on GEBCO Data and Nautical Map
}

\author{
Yulius, H L Salim, M Ramdhan \\ Pusat Litbang Sumberdaya Laut dan Pesisir, Badan Litbang KP, KKP \\ Jalan Pasir Putih I Ancol Timur 14430 Jakarta \\ Corresponding E-mail: yulius.lpsdkp@gmail.com
}

\begin{abstract}
The study aims is to define bathymetry based on General Bathymetric Chart of the Oceans (GEBCO) and Nautical Map using GIS technique. The methods used in this study are the kriging method which combines the spatial correlation among the data using GIS and Remote Sensing software. The result shows that bathymetry at research area can be divided into five classes, these are: (1) 0-2 meter with area of 1.797,61 hectare, (2) 2-5 meter with area of 2.059,06 hectare, (3) 5-10 meter with area of 1.184,02 hectare, (4) 10-25 meter with area of 3.025.00 hectare, (5) 25-200 meter with area of 5.648.62 hectare.The spatial pattern of bathymetry dispersed from the shallow water at the edge of beach and more deep at the offshore, except at the eastern side of Wangi-Wangi island which has barrier reef and created basin between them.
\end{abstract}

Keywords : Bathymetry, GEBCO, Nautical Map, Geographic Information System (GIS),Wangi-wangi Island

\begin{abstract}
Abstrak
Penelitian ini bertujuan untuk menentukan kedalaman perairan dari data General Bathymetric Chart of the Oceans (GEBCO) dan data Peta Laut dengan menggunakan Sistem Informasi Geografis (SIG). Metode yang digunakan dalam penelitian ini adalah metode kriging yang memadukan korelasi spasial antar data, dengan menggunakan perangkat lunak sistem informasi geografis berupa ArGIS 9.3. dan Global Mapper 8.0.Berdasarkan hasil analisis secara spasial, diperoleh bahwa untuk kedalaman perairan pada daerah penelitian dapat dibagi menjadi lima kelas, yaitu: (1) 0-2 meter dengan areal seluas 1.797,61 hektar, (2) 2-5 meter dengan areal seluas 2.059,06 hektar, (3) 5-10 meter dengan areal seluas 1.184,02 hektar, (4) 10-25 meter dengan areal seluas 3.025.00 hektar, (5) 25200 meter dengan areal seluas 5.648 .62 hektar. Pola spasial kedalaman perairan tersebar mulai dari tepi pantai dangkal dan semakin dalam menuju kearah lepas pantai dengan pola semakin menjauhi tepi pantai perairan akan semakin dalam, kecuali di sebelah timur pulau Wangi-wangi terdapat karang penghalang sehingga menciptakan seperti ada basin diantara tepi pantai dan karang penghalang tersebut.
\end{abstract}

Kata kunci : Kedalaman Perairan, GEBCO, Peta Laut, Sistem Informasi Geografis (SIG), Pulau Wangi-wangi

\section{Introduction}

Wakatobi is the name of an island and a regency located in the province of South East Sulawesi. Wakatobi is an acronym for of the main islands that make up the archipelago: Wangi-wangi, Kaledupa, Tomia, and Binongko. Wakatobi is the capital of Wanci, located in Wangi-wangi island. These islands are located in the center of coral reef biodiversity, known as the Coral Triangle Initiative (CTI) (Reef Check, 2007).
Wakatobi Regency is located between the Banda sea to the north-east and the Flores sea to the south-west. It comprisesa land area of $823 \mathrm{~km} 2$ and marine waters covering an area of $18377.31 \mathrm{~km} 2$ (BPS, 2010).

Wakatobi is also the name of the Wakatobi Marine National Park with an area of 1,390,000 ha, designated as a national park by Ministerial Decree No. 393/Kpts-VI/ 1996, concerning marine biodiversity, scale and condition of 
coral; which occupies one of the highest priority position of marine conservation in Indonesia (Ayiful, 2004).

Wakatobi does have its own charm. These islands are also known as the blacksmith Islands which have 25 coral reefs with variuos species. Coral reefs are habitat for many species of fish and other marine species such as molluscs, marine worms, sea plants. Sharks, dolphins, and whales are part of this place. They all create a natural beauty of a marine park which are considered the best in the world and this park is a diving and snorkelingparadise for national and international divers (Rangka and Paena , 2012).
Wakatobi is located in the west of Indonesian archipelagic sea lanes (ALKI/Indonesian ASL) III (Figure 1). Indonesian ASL is defined as the right for the implementation of archipelagic sea lanes based on the international law of the sea convention. It isintended to combine two free waters, the Indian Ocean and the Pacific Ocean which include: Indonesian ASLI passes through the South China Sea - the Karimata Strait - Seribu Islands - the Sunda Strait, Indonesian ASLII passes throughthe Sulawesi Sea - the Makassar Strait - Flores sea - Lombok Strait, Indonesian ASLIII passes through the Pacific ocean - Halmahera Sea - Seram Sea Banda Sea (Ministry of Home Affairs, 2002).

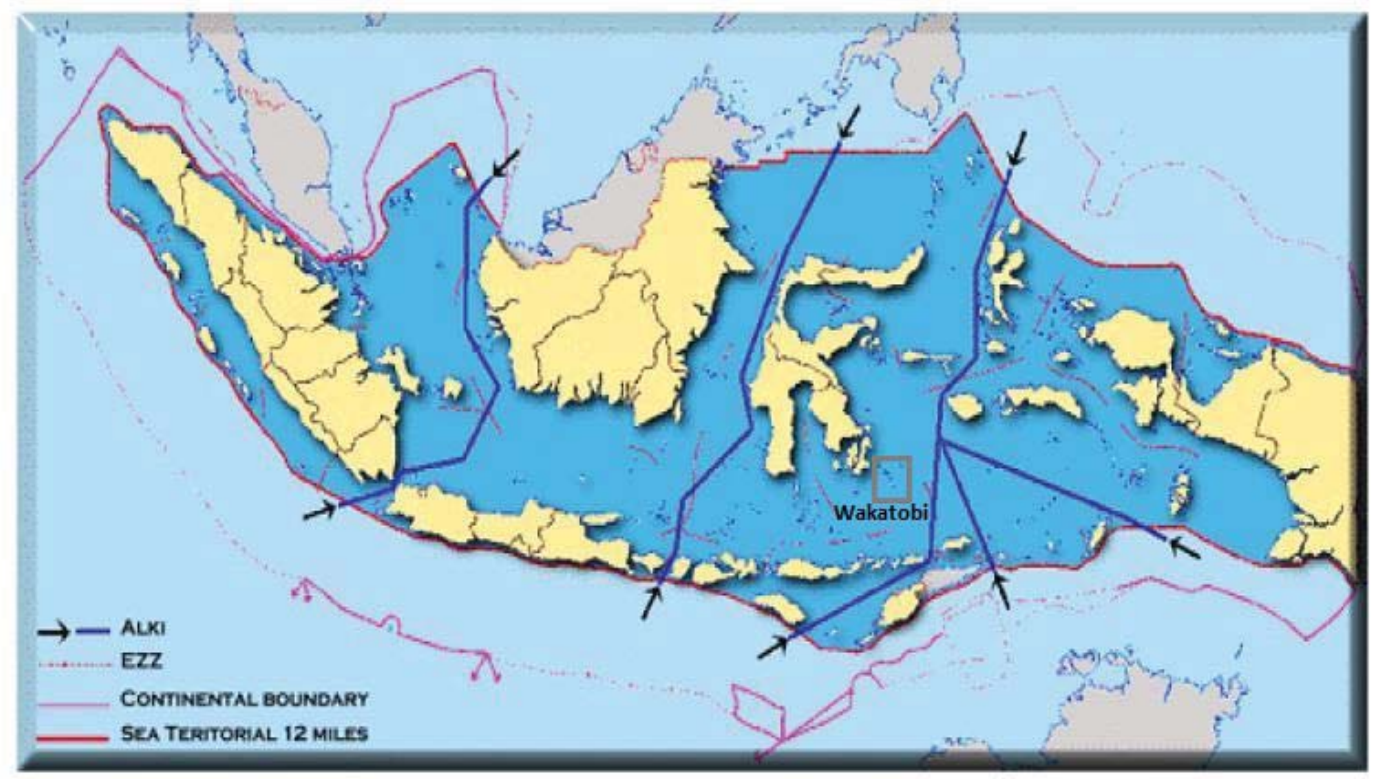

Figure 1. Location of Wakatobi In Indonesian archipelagic sea lanes (ALKI) based onthe PP. 37 year 2002

Bathymetry Map has been used for several purposes, among others; for the boundary delimitations, marine scientific research, development of the region for aquaculture, marine tourism, shipping safety, exploration of marine resources and seabed, coastal engineering, marine modeling, determining the shipping lanes and ports, etc. (Yulius et al., 2011). Bathymetric map processing usually given multiple sets of data and using spatial interpolation to generate a bathymetry surface (Sterling, 2003). One of common way to do spatial interpolation is krigging method. In terms of cartographical, the used of kriging method is effective to illustrate the real world pattern of depth contours (Siregar and Selamat, 2009). 
This study aims to determine the water depth maps (bathymetry) with a scale of 1: 200,000 with its range in hectares from the GEBCO and Nautical chart data using Geographic Information System (GIS). The results expected later will be able to support the exploration of Wangi-wangi island and surrounding areas for marine tourism, shipping safety, determining shipping lanes and ports, fishing and/or aquaculture or other uses.

\section{Method}

\section{Study Location}

This study is conducted in Wangi-wangi island and surrounding areas, Wakatobi district, southeast section of Southeast Sulawesi Province, Geographically positions are $5^{\circ} 12$ '- $6^{\circ} 10^{\prime}$ south latitude and $123^{\circ} 20^{\prime}-124^{\circ}$ 39’ east longitude (Figure 2).

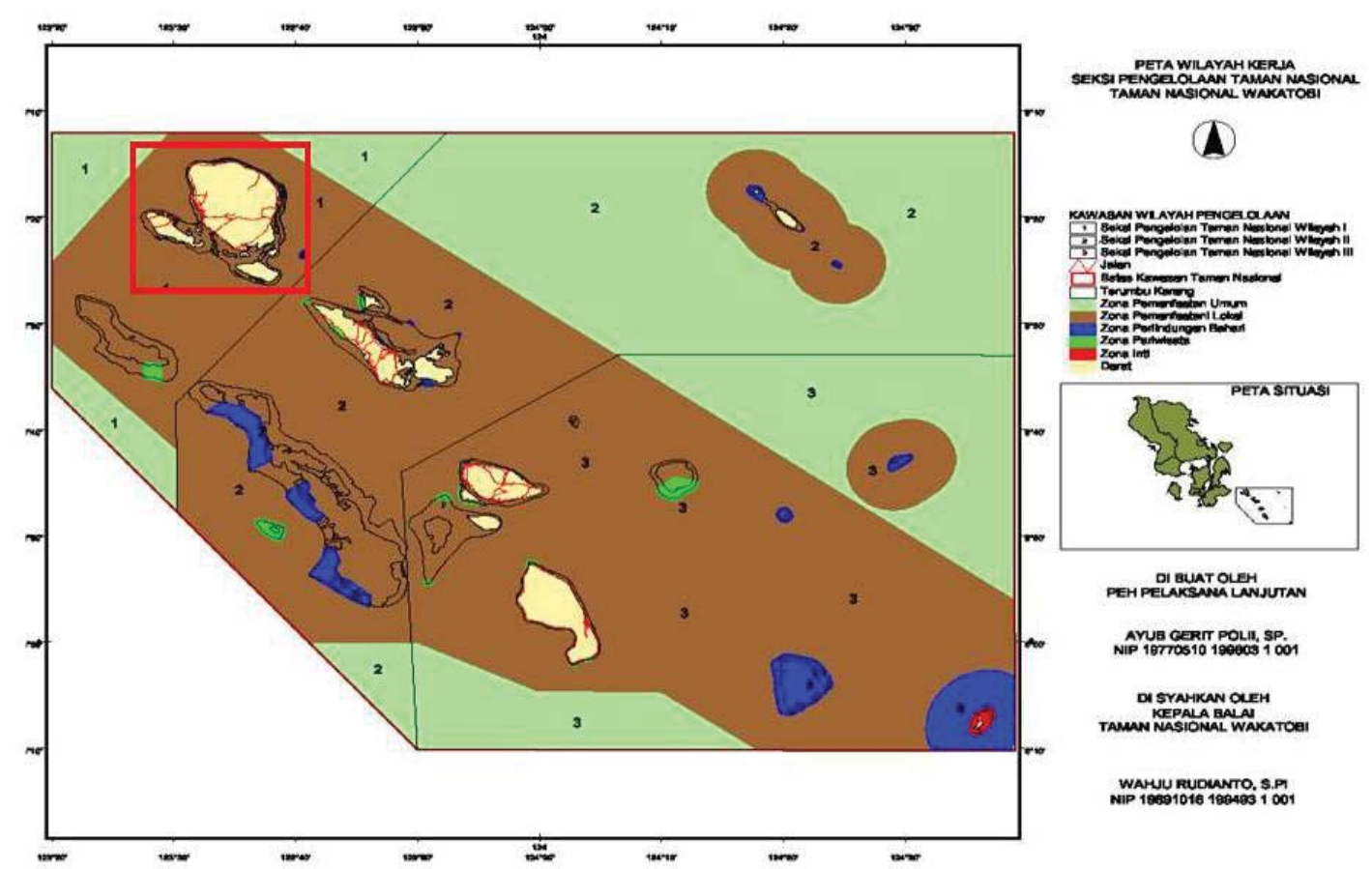

Figure 2. Map of Research Location (red box)(source: BTNW, 2010)

\section{Data and Software}

GEBCO data used in this study are the data with resolution of 30 seconds times 30 seconds (30"x30”) or approximately 1 kilometer times
1 kilometer (1 km x $1 \mathrm{~km})$ with the date ofrecording; May 24, 2013 and the data Map Sea number 317 scale 1: 200,000 in 2001 (Table 1). 
Table 1. The data used in this study

\begin{tabular}{|c|c|c|c|c|c|}
\hline No & Name & Size & Source & Accuracy & Note \\
\hline 1 & $\begin{array}{l}\text { GEBCO data of } \\
\text { Wakatobi (Figure } \\
\text { 3) }\end{array}$ & $2.392 \mathrm{kB}$ & https://www.bodc.ac.uk/ & $\begin{array}{l}1 \mathrm{~km} \mathrm{scale} \\
1: 1,000,000\end{array}$ & $\begin{array}{l}\text { Raster, Resolution } \\
30 \text { "x30", Geograph- } \\
\text { ical Coordinat Sys- } \\
\text { tem, datum WGS-84 }\end{array}$ \\
\hline 2 & $\begin{array}{l}\text { Nautical chart } \\
\text { No. } 317 \\
\text { (Figure 4) }\end{array}$ & $5.372 \mathrm{kB}$ & $\begin{array}{l}\text { Department of Hydro Ocean- } \\
\text { ography ofIndonesian Navy }\end{array}$ & $\begin{array}{l}200 \text { meter scale } \\
1: 200,000\end{array}$ & $\begin{array}{l}\text { Raster, Geographical } \\
\text { Coordinat System, } \\
\text { datum Bessel-1841 }\end{array}$ \\
\hline
\end{tabular}

The tools used to process data consists of geographic information systems desktop software in the form of ARCGIS 9.3 that comes with extension image analysis to perform visual interpretation, digitization process of coastline and water depth line on nautical map and Global Mapper 8.0 to process and display GEBCO Data.

\section{Research Flowchart}

The series of workmanship in making the spatial pattern of water depth in Wangiwangi island and surrounding areas, Wakatobi
Regency, Southeast Sulawesi province in the flowchart can be explained in several stages. First, with an inventory of data GEBCO and Nautical charts which have been digitized. Furthermore, interpolation using kriging method should be performed. It after wards results inbathymetric map which is derived from GEBCO and Nautical chart data. The next stage is the interpolation results should be overlaid and edited. Finally, spatial pattern of water depth of Wangi-wangiisland and surrounding areas is resulted, with classification based on IHO 1998. Stages of the reserach are presented in Figure 3.

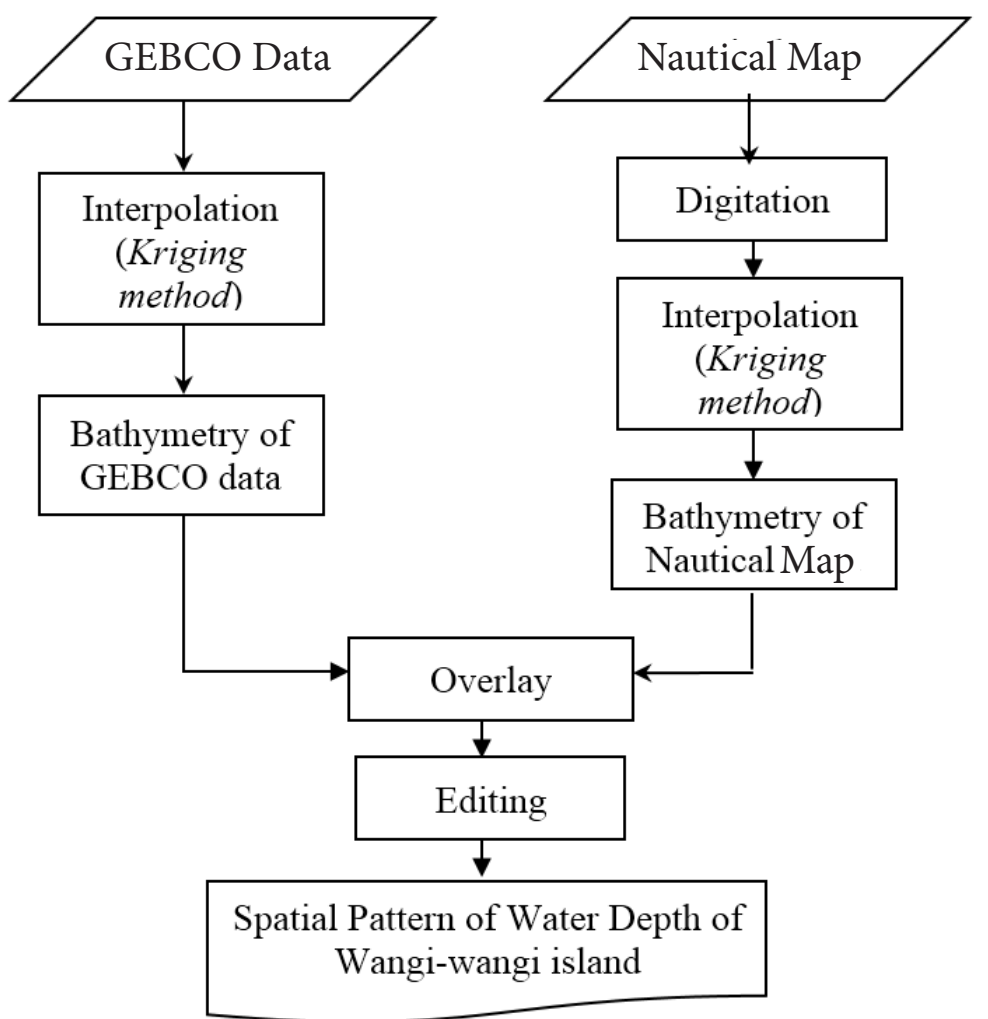

Figure 3. Research Flowchart 
Kriging method has several advantages. Larreche, (2006) in Siregar and Selamat, (2009) states that as interpolator, kriging method combines the spatial correlations among the data, which it was not done by the classical statistical procedures.Compared to other techniques, Kriging method has more advantage that is its ability to identify the variation of the estimated values so that the level of precision can be revealed. Siregar and Selamat (2009) adds that kriging method can still be used even though no correlation is found among the spatial data. In independent observation, kriging estimation process will be similar to the estimation using small squares regression analysis.

\section{Discussion}

Refer to the data of GEBCO and nautical chart which have been digitized, processed and inserted in interpolation processing, in rough interpolation several visual models, either in two or three dimensions, have been created. In the display of two-dimensional interpolation, depth contours on recorded longitudes and latitudes are found, as viewed in figure 4. Meanwhile, three-dimensional interpolation in perspective display with depth color gradient of blue is figured out in Figure 5.

The image of the research location basic profile in the form of visualization of threedimensional interpolation of the data of GEBCO and nautical chart can be seen in figure 5 .

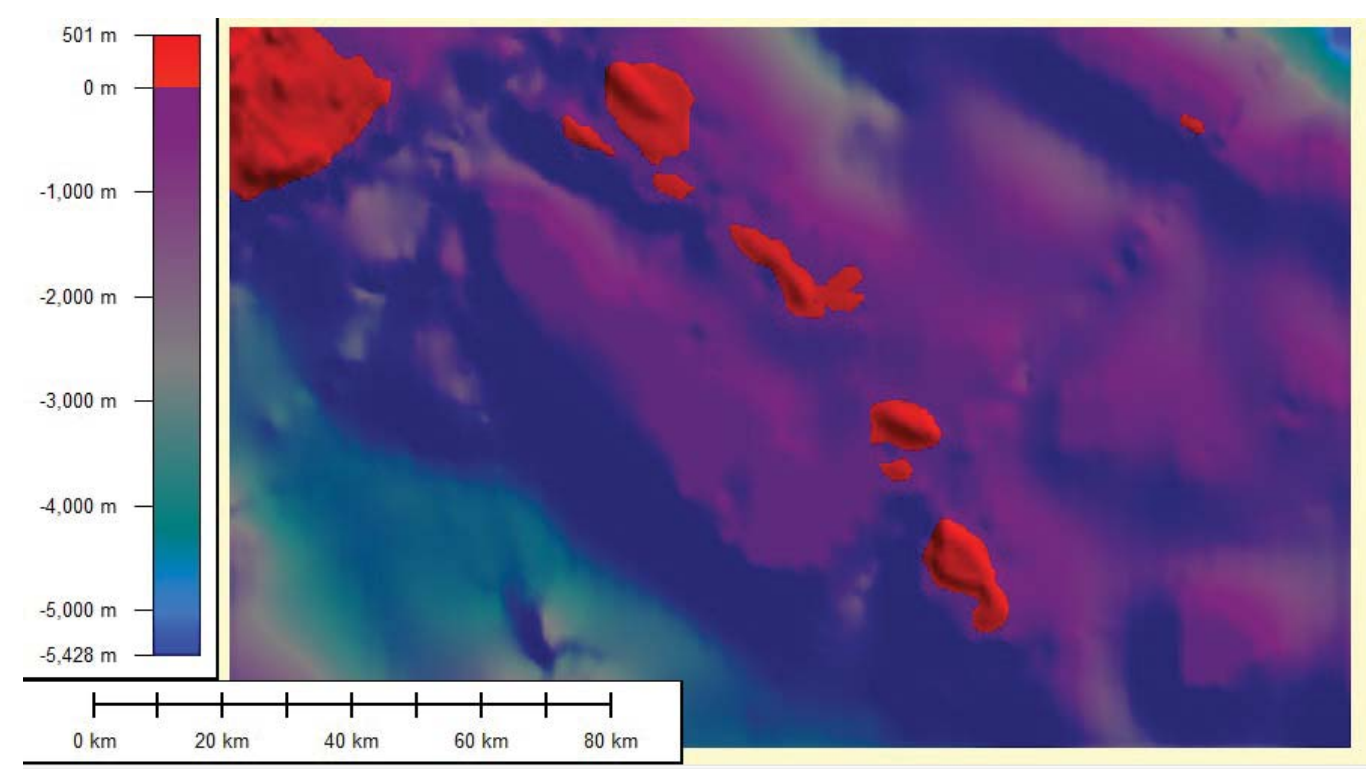

Figure 4. Map of 2-dimensional bathymetry contours of Wakatobi Regency (Source: Gebco 30"bathymetry data) 


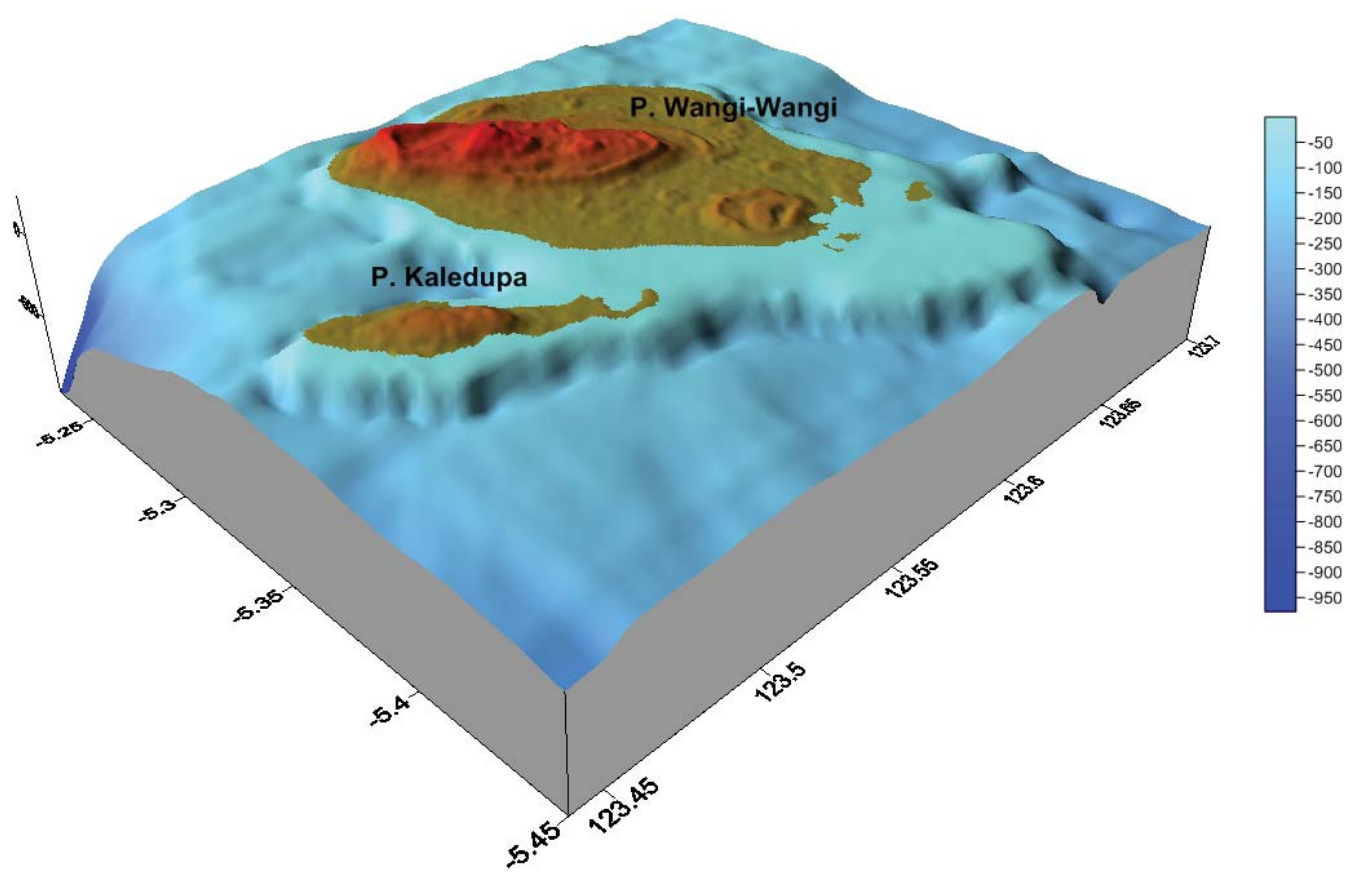

Figure 5. Three-dimensional bathymetry map of Wangi-wangi Island

If seen from the mentioned image of threedimensional basic profile, it is said that the waters of the research locations are harmful enough for shipping route, either for cargo or passenger ships. This is because there exist barrier reefs connecting the islands. Furthermore, in the waters of Wakatobi, the ebb and flow tide currents are relatively strong between the islands. The directions of the ebb and the flow tide currents are north-west and south-east respectively (Dishidros, 2003).

The waters have width of 13,714.31 hectare and depth of 200 meters. The condition of ocean floor topography on the areas of waters near the shore changes gradually from deep to steep. Moreover, the depth of the ocean floor to outer island topography becomes steep with sloping topography condition.

Based on the results of spatial analysis, it is concluded that the depth of the waters is classified into five groups: (1) group of $0-2$ meters with area of 1,797.61 hectares, (2) group of 2-5 meters with area of 2,059.06 hectares, (3) group of 5-10 meters with area of $1,184.02$ hectares, (4) group of $10-25$ meters with area of 3,025.00 hectares, (5) group of 25-200 meters with area of 5,648.62 hectares, as exhibited in Table 2 . The spatial distribution map of water depth (bathometer) is shown by Figure 6.

Table2. The area of bathymetry

\begin{tabular}{cccc}
\hline No & $\begin{array}{c}\text { Water Depth/ } \\
\text { Bathymetry (m) }\end{array}$ & Area (ha) & Width $\left(\mathrm{km}^{2}\right)$ \\
\hline 1 & $0-2$ & $1,797.61$ & 17.98 \\
2 & $2-5$ & $2,059.06$ & 20.59 \\
3 & $5-10$ & $1,184.02$ & 11.84 \\
4 & $10-25$ & $3,025.00$ & 30.25 \\
5 & $25-200$ & $5,648.62$ & 56.49 \\
& Total Area & $13,714.31$ & 137.14 \\
\hline
\end{tabular}

As shown by the aforementioned figure, it is clear that the basic profile of the sea is included as deep water. The water depth measured from the seashore to outer island ranges from 2 to 200 meters. The deepest part is located in the east of Kampenaune Island with maximum depth of 183 meters. Islands are connected by reefs with gradually-increasing basic profile ranging from 14 to 3 meters deep. The shore area around the reefs is included as slope area with the width starting from 2 meters to 100 
meters steep. Its distance is approximately 75 meters, close enough from the coastline.

The water depth profile represents the condition of shallow water shore, going deeper to off shore or slope. The condition generally happens in the research locations except in the east of Wangi-wangi whose barrier reefs appear and they hence create basin between the seashore and reefs as displayed in figure 6 .

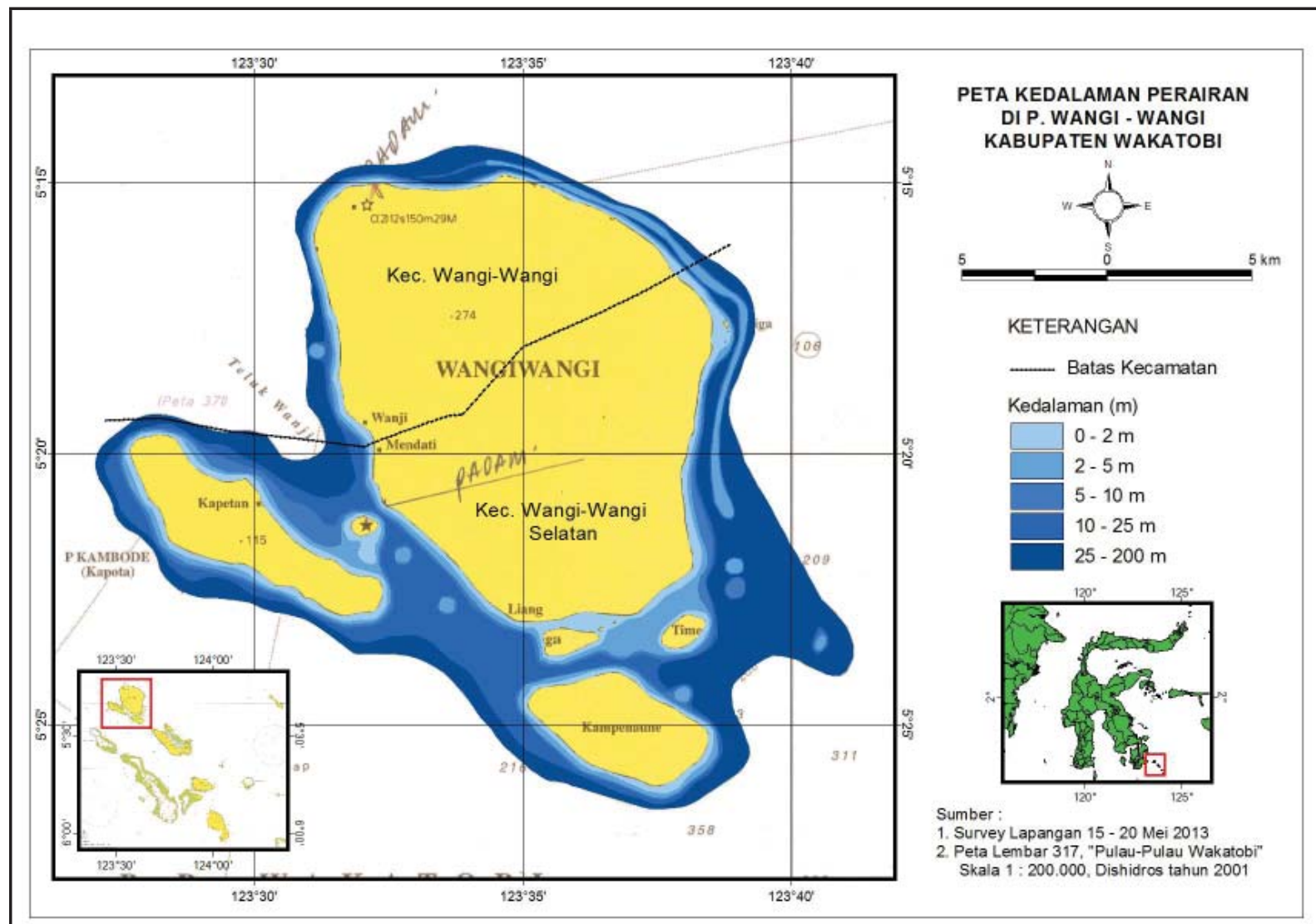

Figure 6. Bathymetry Map of Wangi-wangi Island

The research locations consist of WangiWangi, Kambode (Kapota), Kampenaune islands and some smaller islands between, connected by reefs (Figure 7). In front of the northern and eastern shore of Wangi-wangi, there are narrow barrier reefs, parallel to the coast line in the distance of 200-500 meters and therefore slot with depth of 25-50 meters is formed. The reefs are parallel to the northern shore with varying depths between 1.5 and 11 meters (Dishidros, 2003). In the east of Wangi-wangi Island, there exist barrier reefs which are harmful enough for shipping route (Figure 8). The appearing reefs lay close to the depth line of 25-200 meters. On the lowest ebb, people can pass through the reefs to head to Tiga Island on foot. 


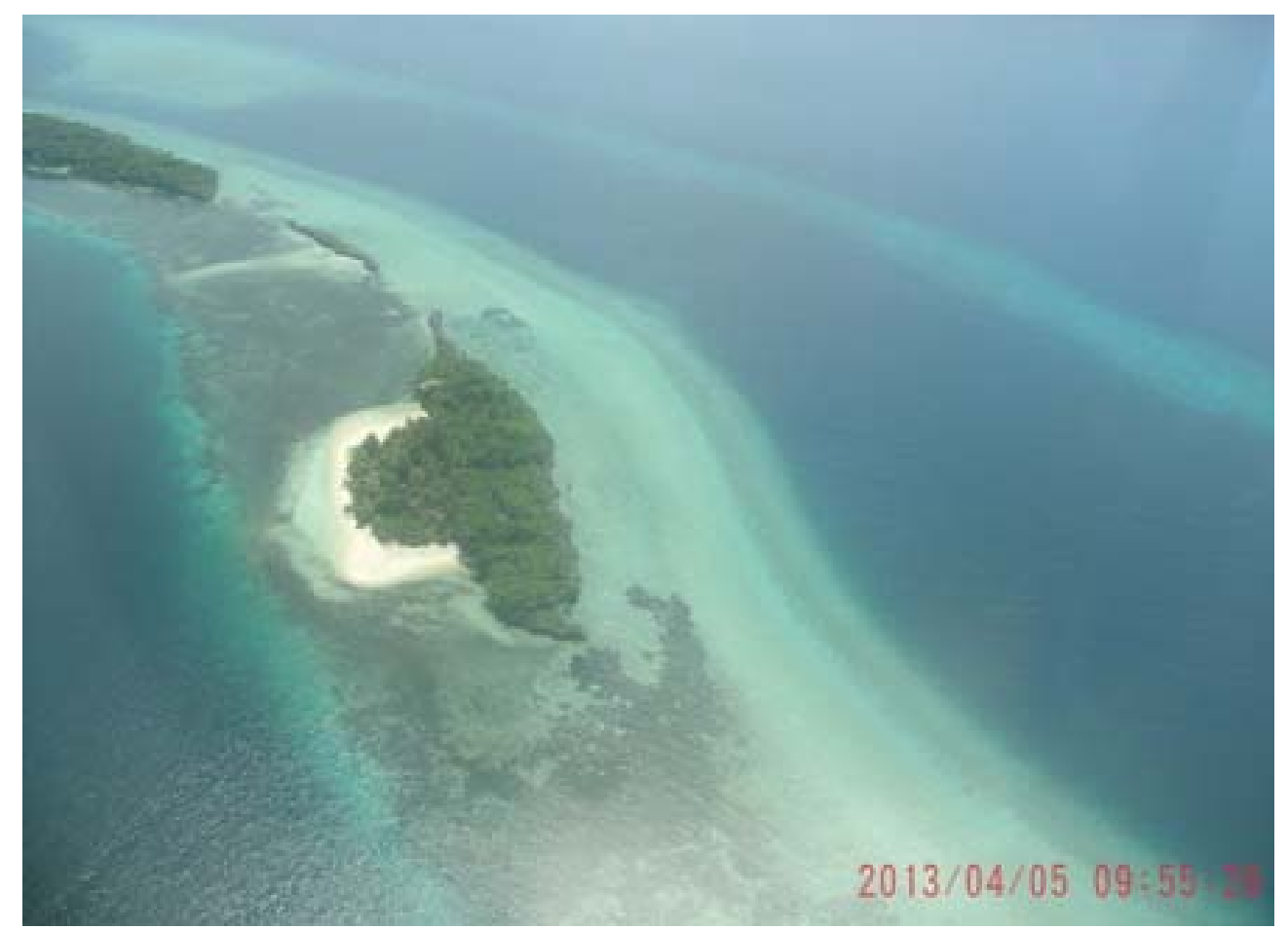

Figure7. Linking coral islands around Wangi-wangi Island

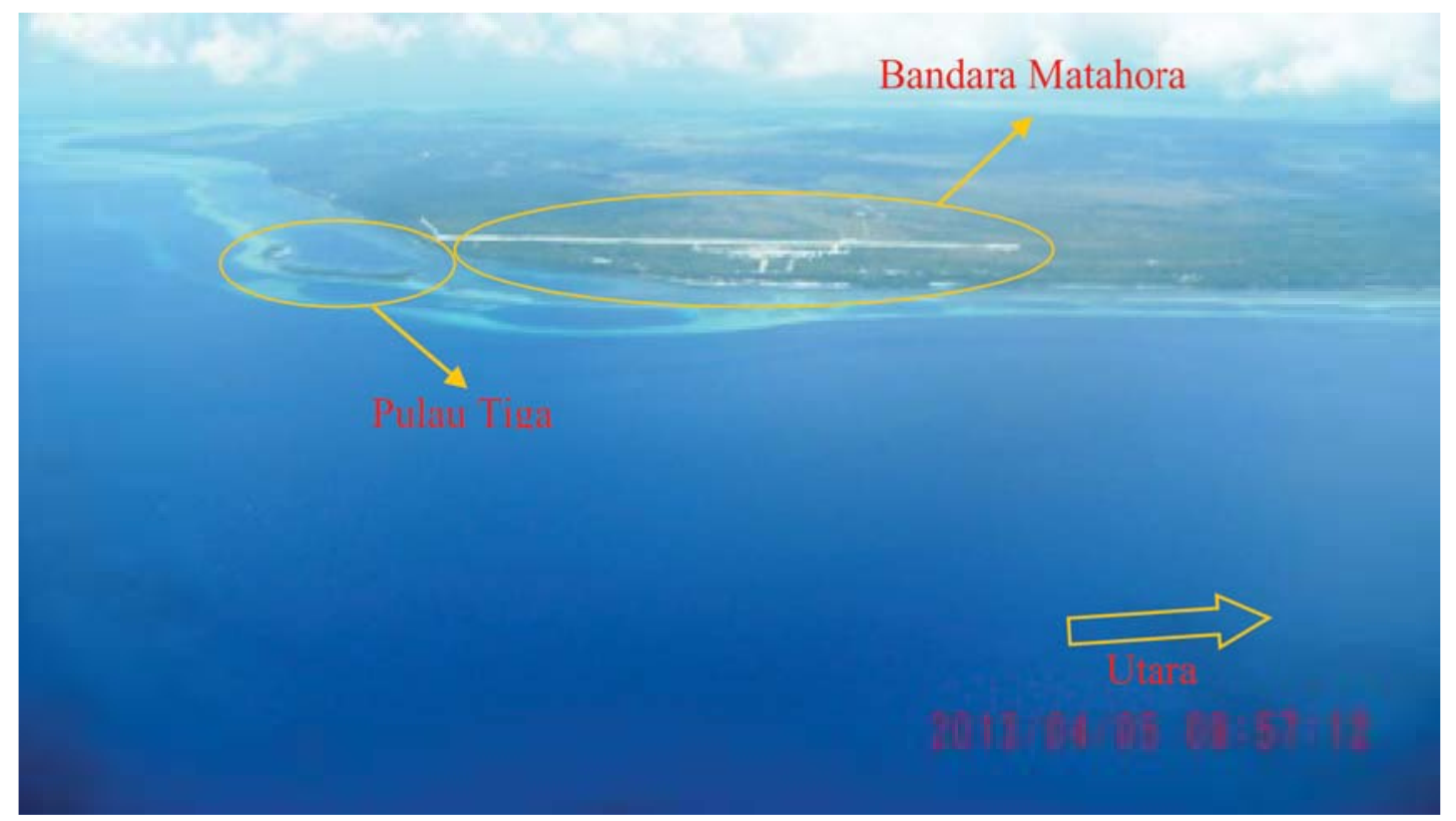

Figure 8. Barrier reef in front of Matahora Wakatobi airport, Wangi-wangi Island 


\section{Conclusion}

In the north and east of Wangi-wangi islandare narrow barrier reefs, which are parallel with the shoreline within 200-500 meters, forming a groove with a depth of 25-50 meters. The barrier reefs at the northern coast havetheir depths varies between 1.5 and 11 meters.

Based on the results of spatial analysis, it is revealed that the depth of the waters in the research area can be divided into five classes, namely: (1) 0-2 meter with an area of 1,797.61 hectares, (2) 2-5 meters with an area of 2,059.06 hectare, (3) 5-10 meters with an area of 1,184.02 hectares, (4) 10-25 meters with an area of 3,025.00 hectares, (5) 25-200 meters with an area of 5,648.62 hectares. Depth profiles show that the beach is getting shallower and deeper towards theoffshore. This generally is happened in the research location except in the east of the island that there are barrier reefs, creating something likea basin between the beach shore and those reefs.

\section{Acknowledgement}

The researchers express their deepest gratitude to the Center of Marine and Coastal Resources, Research-KP, on funding this research.

\section{References}

Ayiful, R.A. 2004. Strategi Pengembangan Kegiatan Pariwisata di Taman Nasional Kepulauan Wakatobi Sulawesi Tenggara [Tugas Akhir]. Semarang: Universitas Dipenogoro.

Badan Pusat Statistik (BPS). 2010.Kabupaten Wakatobi dalam Angka Tahun 2010.Badan Pusat Statistik (BPS). Wanci. 1-15hlm.

Balai Taman Nasional Wakatobi. 2010. Statistik Balai Taman Nasional Wakatobi 2009/2010. Jakarta.

Canadian Hydrographic Service Fisheries and Oceans. 1998. Standard for Hydrographic Survey $2^{\text {nd }}$ edition. Canada

Dinas Hidro-Oseanografi TNI-AL (Dishidros). 2003. Kepanduan Bahari Indonesia Jilid II.Dinas Hidro-Oseanografi TNI-AL. Jakarta. 723-752hlm.

Kementerian Dalam Negeri. 2002.Peraturan Pemerintah Republik Indonesia Nomor 37 Tahun 2002 Tentang Hak dan Kewajiban Kapal dan Pesawat Udara Asing dalam Melaksanakan Hak Lintas Alur Laut Kepulauan Melalui Alur Laut Kepulauan yang Ditetapkan. Jakarta. 1-20hlm.

Rangka, N.A., dan Paena, M. 2012. Potensi dan Kesesuaian Lahan Budidaya Rumput Laut (Kappaphycus Alvarezii) di Sekitar Perairan Kabupaten Wakatobi Provinsi Sulawesi Tenggara. J. Ilmiah Perikanan dan Kelautan, 4(2):151-159.

Reef Check Indonesia. 2007. Satu Dekade Pemantauan Reef Check: Kondisi dan Kecenderungan pada Terumbu Karang Indonesia. www.reefcheck.or.id

Siregar, V.P., dan Selamat, M.B. 2009. Interpolator Dalam Pembuatan Kontur Peta Batimetri. J. Ilmu dan Teknologi Kelautan Tropis:1(1):39-47.

Starling, L. D. 2003. A Comparison of Spatial Interpolation Techniques For Determining Shoaling Rates of The Atlantic Ocean Channel. Thesis. Faculty of the Virginia Polytechnic Institute and State University. Blacksburg. Virginia.

Yulius,Prihatno, H., dan Suhelmi, I.R. 2011. Pola Spasial Kedalaman Perairan di Teluk Bungus, Kota Padang.Prosiding Pertemuan Ilmiah Nasional Tahunan VII ISOI 2010:205-212. 